\title{
KARAKTERISASI ENZIM SELULASE PMP 0126Y DARI LIMBAH PENGOLAHAN AGAR
}

\section{Characterization of PMP 0126Y Cellulase Enzyme from Agar Processing Waste}

\author{
Ekowati Chasanah ${ }^{1 *}$, Isna Rahma Dini ${ }^{2}$, dan Nisa Rachmania Mubarik ${ }^{3}$ \\ ${ }^{1}$ Balai Besar Penelitian dan Pengembangan Pengolahan Produk dan Bioteknologi Kelautan dan Perikanan, KKP. \\ JI. KS Tubun, Petamburan VI, Jakarta 10260 \\ 2 Program Studi Agroteknologi Fakultas Pertanian, Universitas Riau, Riau \\ ${ }^{3}$ Program Studi Bioteknologi Pasca Sarjana IPB, Bogor \\ Korespondensi Penulis: ekowatichasanah@gmail.com
}

Diterima: 29 April 2013 Disetujui: 10 Oktober 2013

\begin{abstract}
ABSTRAK
Hasil penapisan bakteri penghasil enzim selulase terdahulu mendapatkan isolat PMP 0126 sebagai isolat yang berpotensi yang diisolasi dari limbah pengolahan agar skala UKM di Pamengpeuk, Garut. Isolat tersebut ternyata belum merupakan koloni tunggal, terdiri dari 2 isolat bakteri yaitu PMP 0126Y dan PMP 0126W. Isolat PMP 0126Y memiliki kemampuan mendegradasi selulosa yang lebih besar dibanding PMP 0126W. Tujuan dari penelitian ini adalah untuk memproduksi dan mengkarakterisasi enzim selulase dari isolat PMP 0126Y, serta mengidentifikasi isolat tersebut. Hasil penelitian menunjukkan bahwa enzim selulase diproduksi optimum pada hari ke-3 kultivasi menggunakan medium cair berisi CMC 1\%. Enzim kasar yang diperoleh dapat bekerja optimal pada suhu $30{ }^{\circ} \mathrm{C}$ dan $\mathrm{pH} \mathrm{5}$, dapat ditingkatkan aktivitasnya dengan ion logam dalam bentuk garam $\mathrm{CaCl}_{2}$ dan $\mathrm{ZnCl}_{2} 5 \mathrm{mM}$. Pemurnian dengan sistem penukar anion dapat meningkatkan aktivitas enzim 15x dengan perolehan 20\%. Dari hasil SDS-PAGE terlihat bahwa ada 3 selulase dengan perkiraan berat molekul 39, 30, dan 14 kDa. Enzim kasar ini memiliki kemampuan menghidrolisis limbah pengolahan agar sebaik ketika memecah substrat CMC, yang mengindikasikan bahwa enzim dari isolat ini berpotensi sebagai kandidat agen sakarifikasi pada produksi bioetanol. Identifikasi bakteri dengan 16S-rDNA menunjukkan bahwa isolat ini memiliki kemiripan 96\% dengan bakteri Chryseobacterium indologenes McR-1.
\end{abstract}

KATAKUNCl: limbah pengolahan agar, selulase, karakterisasi, isolat PMP 0126Y

\begin{abstract}
From previous screening study, PMP 0126 has been identified as one of potentially isolate from medium scale agar processing industries in Pamengpeuk, Garut. However, PMP 0126 was not pure yet, containing 2 isolates PMP $0126 \mathrm{Y}$ and PMP 0126W. PMP $0126 \mathrm{Y}$ produced higher celullase compared to the PMP 0126W. Aims of this study was to produce and characterize PMP $0126 Y$ cellulase and identify the isolate. Result showed that the cellulase was optimally produced on the third days of cultivation using 1\% CMC medium. Crude enzyme worked optimally at temperature of $30^{\circ} \mathrm{C}$ and $\mathrm{pH} 5$, and the activity could be improved by addition of $5 \mathrm{mM} \mathrm{CaCl}_{2}$ and $\mathrm{ZnCl}_{2}$ Purification using anion exchanger could improve the activity 15 times with yield of $20 \%$. $P M P^{2} 0126 Y$ produced 3 cellulases with estimated molecular weight of 39, 30 dan $14 \mathrm{kDa}$. The crude enzyme could degrade the agar processing waste as good as CMC, indicating that this enzyme could be used as saccharification agent for bioethanol processing from agar processing waste. Identification study showed that this isolate was $96 \%$ similar to Chryseobacterium indologenes $M c R-1$.
\end{abstract}

KEYWORDS: $\quad$ agar processing waste, cellulase, characterization, PMP 0126Y isolate

\section{PENDAHULUAN}

Kementerian Kelautan Perikanan telah mencanangkan produksi hasil kelautan dan perikanan termasuk rumput laut, sebesar $353 \%$ sampai dengan
Tahun 2014. Pusat-pusat budidaya rumput laut telah dikembangkan di seluruh wilayah Indonesia dan rencana pengembangan skala usaha industri pengolahan rumput laut baik yang telah ada maupun yang akan dikembangkan telah direncanakan oleh 
Direktorat Pengolahan Hasil Perikanan, Kementerian Kelautan dan Perikanan (Anon., 2012).

Industri agar dilaporkan menghasilkan limbah sebesar $65-75 \%$, yang masih memiliki selulosa sebesar 19,7\% (Kim et al., 2008), selulosa merupakan jenis karbohidrat terbanyak nomor 2 setelah kitin. Salah satu alternatif pemanfaatan limbah rumput laut dari industri pengolahan rumput laut yaitu dengan memproses selulosa yang masih terkandung dalam limbah dengan jumlah yang cukup besar menjadi etanol. Pemanfaatan limbah selulosa dan bakteri penghasil enzim penghidrolisis selulosa dapat memberikan peluang pada pengembangan bioenergi dari bahan hayati laut.

Proses hidrolisis selulosa dapat dilakukan dengan menggunakan asam dan suhu tinggi. Proses ini relatif mahal karena membutuhkan energi yang besar serta dapat mengakibatkan degradasi produk monosakarida yang dihasilkan sehingga produk yang dihasilkan rendah. Selain itu, Riyanti (2008) melaporkan efisiensi proses hidrolisis dengan asam masih rendah karena proses yang dilakukan cukup panjang dan membutuhkan banyak tahapan. Kekurangan lain dari proses ini antara lain yaitu penanganan limbah asam yang tidak mudah. Hidrolisis selulosa dengan menggunakan enzim selulase mulai dikembangkan pada tahun 1980-an (Coral et al., 2002). Hidrolisis secara enzimatik melibatkan proses yang lebih ramah lingkungan, efisien, dan murah karena tidak memerlukan energi tinggi.

Enzim selulase merupakan sistem enzim yang terdiri atas tiga tipe enzim utama yaitu endo- $\beta$ glucanase (EC 3.2.1.4), exo- $\beta$-glucanase (EC 3.2.1.91) dan $\beta$-glucosidase (EC 3.2.1.21). Endo- $\beta$-glucanase, $1,4-\beta$-D-glucan glucanohydrolase, CMCase, Cx: "random" memutus rantai pada selulosa dan menghasilkan glukosa dan oligosakarida. Exo- $\beta$ glucanase, 1,4- $\beta$-D-glucan cellobiohydrolase, avicelase, $\mathrm{C} 1$ akan menghidrolisis selulosa dari sisi non reduksi, menghasilkan selobiosa sedangkan $\beta$ glucosidase, cellobiase akan menghidrolisis cellobiosa menjadi glukosa (Crueger \& Crueger, 1984; Anon., 2013). Ketiga enzim ini bekerja secara sinergis mendegradasi selulosa dan melepaskan gula reduksi (selobiosa dan glukosa) sebagai produk akhirnya. Enzim selulase akan memutuskan ikatan glikosidik $\alpha-$ 1,4 di dalam selulosa yang memiliki ikatan $\alpha-1,4-$ glikosidik pada polimer glukosanya sehingga menjadi gula sederhana turunannya.

Penapisan selulase di Indonesia telah dilakukan di antaranya dari tanah (Meryandini et al., 2009; Lisdiyanti et al., 2012). Mangunwardoyo et al. (2011) telah melaporkan selulase dari yeast yang telah diisolasi dari tanah, air sungai dan sedimen Taman
Nasional Gunung Halimun (TNGH). Isolasi selulase bakteri dari lingkungan laut dari rumput laut Ulva lactuca telah dilaporkan oleh Trivedi et al. (2011). Shanmunghapriya et al. (2010) telah mengisolasi selulase dari spons laut Dendrilla nigra, sedangkan Gao et al. (2010) melaporkan bakteri selulolitik dari tanah sekitar mangrove.

Dari kegiatan sebelumnya, penapisan bakteri selulolitik telah dilakukan utamanya dari rumput laut dan limbah pengolahan rumput laut (Munifah et al., 2011). Dari kegiatan tersebut didapatkan salah satu bakteri yang memiliki potensi sebagai bakteri selulolitik, yaitu isolat PMP 0126 yang berhasil diisolasi dari limbah pengolahan agar-agar rumput laut Glacilaria sp. dari daerah Pameungpeuk, Garut Jawa Barat (Munifah et al., 2011). Ide dilakukannya isolasi bakteri dari limbah rumput laut ini yaitu diperolehnya bakteri selulolitik hasil isolasi untuk mendegradasi selulosa dari limbah rumput laut ekonomis maupun rumput laut non ekonomis sebagai agen sakarifikasi untuk produksi bioetanol. Sebagaimana dilaporkan oleh FAO (Anon., 2013) bahwa keberhasilan penggunaan selulosa untuk sumber karbon yang bersifat dapat diperbaharui (bioenergi) sangat tergantung dari teknologi proses yang secara ekonomis menguntungkan untuk produksi selulase. Selulase yang diproduksi secara lokal diharapkan akan banyak mengurangi beban biaya produksi bioenergi/ bioetanol.

Isolat PMP 0126 ternyata belum murni, dan hasil pemisahan lanjutan mendapatkan 2 isolat bakteri dari isolat PMP 0126, yaitu isolat bakteri 0126Y dan 0126W. Dari hasil pengujian kualitatif menunjukkan bahwa isolat PMP 0126Y memiliki kemampuan lebih besar dalam memecah selulosa, yaitu menghasilkan indeks selulolitik sebesar 1,9 dibanding isolat PMP 0126W yang menghasilkan indeks selulolitik sebesar 1. Berdasarkan hasil pengujian kualitatif tersebut, maka selanjutnya isolat PMP 0126Y digunakan untuk penelitian ini. Tujuan dari penelitian ini adalah memproduksi dan mengkarakterisasi enzim selulase yang dihasilkan oleh isolat PMP 0126Y serta melakukan identifikasi bakteri tersebut.

\section{BAHAN DAN METODE}

\section{Penyegaran dan identifikasi isolat PMP 0126Y}

Isolat PMP 0126Y disegarkan dengan cara menumbuhkan isolat pada media padat berisi nutrient agar (NA) dan diinkubasi pada suhu $37^{\circ} \mathrm{C}$ (24 jam). Identifikasi berdasar gen 16S-rDNA dilakukan mengikuti Suwanto et al. (2000). Analisis Cluster 
terhadap urutan (sekuens) basa pada gen hasil amplifikasi PCR dilakukan menggunakan European Bioinformatics Institute (http://www.ebi.ac.uk) dan National Center Biotechnology Information (NCBI), sedangkan pembuatan pohon kekerabatan (phylogenetic tree) dilakukan menggunakan program Treecon (Van de Peer \& De Watcher, 1993).

\section{Kurva pertumbuhan dan waktu produksi enzim}

Kurva pertumbuhan isolat PMP 0126Y dilakukan mengikuti Lee (2006) dengan cara menumbuhkan isolat ke dalam $10 \mathrm{ml}$ nutrient broth (NB) dan diinkubasi selama $12-14$ jam. Kultur diinkubasi pada suhu $30^{\circ} \mathrm{C}$ di dalam penangas goyang (Shel Lab) dengan kecepatan agitasi $150 \mathrm{rpm}$. Sampling dilakukan selama 27 jam dengan rentang waktu sampling 3 jam untuk diukur nilai Optical Density (OD) pada panjang $\lambda=600 \mathrm{~nm}$. Penghitungan jumlah koloni total pada cawan (TPC) juga dilakukan untuk memperkirakan jumlah sel bakteri pada setiap nilai OD yang dihasilkan.

Penentuan waktu produksi enzim selulase menggunakan starter $10 \%$ yang dilakukan pada skala $25 \mathrm{ml}$ media cair yang mengandung CMC 1\% dalam $250 \mathrm{ml}$ erlenmeyer. Pengambilan sampel dilakukan setiap hari selama 6 hari waktu inkubasi. Larutan sampel disentrifugasi pada suhu $4{ }^{\circ} \mathrm{C}$ dengan kecepatan $9000 \mathrm{xg}$ selama 10 menit, dan supernatan yang dihasilkan berupa enzim kasar ekstraseluler yang kemudian diuji aktivitasnya.

\section{Pengujian aktivitas enzim}

Pengujian aktivitas enzim dilakukan dengan menggunakan metode DNS Wood (1988) dalam Arifin (2006) yang dimodifikasi. Substrat (1,8 ml) dalam 0,1 $\mathrm{M}$ bufer sitrat fosfat $\mathrm{pH} 5$ ditambah dengan $0,2 \mathrm{ml}$ enzim kasar, dikocok kuat dengan vortex, selanjutnya diinkubasi selama 30 menit pada suhu $30^{\circ} \mathrm{C}$. Reaksi enzim dihentikan dengan mencelupkan (10 menit) campuran reaksi ke dalam penangas berisi air mendidih. Setelah itu, diambil campuran reaksi sebanyak $1 \mathrm{ml}$, ditambah dengan $1 \mathrm{ml}$ DNS, dan dipanaskan dalam air mendidih selama 15 menit. Setelah dingin, absorbansi diukur pada $\lambda=575 \mathrm{~nm}$. Perlakuan kontrol dan blanko dilakukan secara bersamaan dengan tahapan yang sama. Pada kontrol, enzim yang akan direaksikan dengan substrat telah diinaktivasi terlebih dahulu dengan memanaskan enzim selama 15 menit dalam air mendidih. Sedangkan pada blanko, larutan enzim diganti dengan akuades untuk direaksikan dengan substrat. Aktivitas selulase dinyatakan dalam satuan internasional yaitu $\mathrm{U} / \mathrm{ml}$. Satu unit merupakan jumlah enzim yang dibutuhkan untuk memecah $1 \mu \mathrm{mol}$ selulosa menjadi gula pereduksi per menit pada kondisi pengujian. Aktivitas enzim dihitung berdasarkan Irawan et al. (2008).

\section{Pemurnian Enzim Selulase}

Pemurnian enzim dilakukan dengan metode penukar ion mengikuti Li-Jung et al. (2010) dengan modifikasi. Pemurnian dilakukan dengan menggunakan Akta purifier. Sebagai fase diamnya adalah DEAE Sepharose ${ }^{\text {TM }}$ Fast Flow (AmershamBioscience, Upsalla Sweden), dan buferTris- $\mathrm{HCl} 0,05$ $\mathrm{M} \mathrm{pH} 8$ dengan gradien konsentrasi $\mathrm{NaCl}$ dalam Tris$\mathrm{Cl} 0,05 \mathrm{M} \mathrm{pH} 8$ sebagai fase geraknya. Elusi protein enzim target dilakukan dengan mengalirkan gradien $\mathrm{NaCl} 0-0,5 \mathrm{M}$.

\section{Analisis Elektroforesis SDS-PAGE dan Zimogram}

SDS-PAGE dilakukan menurut Bollag \& Edelstein (1991) dengan menggunakan $10 \%$ poliakrilamida sebagai gel pemisah dan $4 \%$ poliakrilamida sebagai gel pengumpul atau penahan. Elektroforesis dilakukan pada tegangan 100 volt dan $50 \mathrm{~mA}$ di dalam piranti elektroforesis (Amersham Bioscience, Swedia).

Zimogram dilakukan dengan mengembangkan metoda Nack-Shick et al. (2006). Substrat 0,1\% ditambahkan pada gel, dan setelah selesai proses elektroforesis, renaturasi dilakukan pada gel yang mengandung substrat tersebut dengan cara merendam gel di dalam 2,5\% Triton X-100 selama satu jam sambil digoyang konstan. Gel ditiriskan dan direndam dalam $0,05 \mathrm{M}$ bufer sitrat posfat $\mathrm{pH} 5$ selama 1,5-2 jam sambil digoyang perlahan dalam inkubator goyang pada suhu $30^{\circ} \mathrm{C}$. Kemudian gel diwarnai dengan $0,1 \%$ congo red selama 30 menit, selanjutnya direndam dengan $1 \mathrm{M} \mathrm{NaCl}$ selama 15 menit. Zona bening disekitar pita menunjukkan adanya aktivitas enzim.

\section{Pengukuran Kadar Protein}

Pengukuran kadar protein dilakukan dengan menggunakan metode Bradford (1976).

\section{Karakterisasi Enzim}

Penentuan $\mathrm{pH}$ optimum dilakukan dengan mereaksikan enzim dan substrat yang memiliki berbagai tingkatan $\mathrm{pH}$ yaitu $\mathrm{pH} 3,4,5(0,05 \mathrm{M}$ bufer asetat), $\mathrm{pH} 5,6,7$ (0,05 $\mathrm{M}$ buffer sitrat fosfat), dan $\mathrm{pH}$ 7, 8, 9 (0,05 M bufer Tris $\mathrm{HCl})$. Penentuan suhu optimum dilakukan dengan mereaksikan substrat dan enzim pada tingkatan suhu antara $30^{\circ} \mathrm{C}$ sampai dengan $90^{\circ} \mathrm{C}$ dengan selang $10^{\circ} \mathrm{C}$ selama 30 menit waktu inkubasi. Pengukuran stabilitas panas enzim dilakukan dengan memanaskan enzim selulase selama 15, 30, 45, 60, 90, 120, dan 240 menit pada suhu optimum enzim. 
Pengujian substrat spesifik dilakukan dengan menguji selulase PMP 0126Y pada berbagai substrat (CMC teknis dan CMC murni, avisel, kertas Wathman filter paper No. 1, limbah rumput laut pengolahan agar PT. Agarindo, limbah rumput laut pengolahan agar Pemeungpeuk dan limbah pengolahan alginat dari rumput laut Sargassum). Aktivitas diukur pada kondisi (suhu dan $\mathrm{pH}$ ) optimal enzim tersebut. Kestabilan enzim pada bahan aditif dilakukan dengan menggunakan $5 \mathrm{mM}$ dan $10 \mathrm{mM}$ ion logam $\mathrm{KCl}, \mathrm{NaCl}$ (monovalen), $\mathrm{CaCl}_{2} \cdot 2 \mathrm{H}_{2} \mathrm{O}, \mathrm{MgSO}_{4} \cdot 7 \mathrm{H}_{2} \mathrm{O}, \mathrm{ZnCl}_{2}$ (divalen), dan $\mathrm{FeSO} 4 \cdot 7 \mathrm{H}_{2} \mathrm{O}$ (trivalen).

\section{HASIL DAN BAHASAN}

Isolat PMP 0126Y yang digunakan pada penelitian merupakan hasil pemurnian ulang isolat PMP 0126 penghasil enzim selulase yang telah diisolasi dari limbah pengolahan rumput laut hasil penapisan sebelumnya (Munifah et al., 2011). Dari 2 hasil pemurnian ulang diperoleh 2 isolat yaitu PMP 0126Y dan PMP 0126P, selanjutnya isolat PMP 1026Y dipilih untuk digunakan dalam penelitian ini dan dilakukan identifikasi ulang. Dari hasil pewarnaan gram, isolat PMP 1026Y adalah bakteri Gram negatif berbentuk batang pendek. Berdasarkan identifikasi menggunakan primer $16 \mathrm{~S} r$-DNA, isolat PMP 0126Y memiliki kemiripan sebesar $96 \%$ dari 1282 nukleotida yang overlapped (bertumpang tindih) dengan 1234 nukleotida dari bakteri Chryseobacterium indologenes galur McR-1. Gambar 1 memperlihatkan pohon filogenetik yang menggambarkan posisi isolat PMP 0126Y dengan beberapa bakteri genus Chryseobacterium dan bakteri penghasil enzim selulase.

Yi-Tsung et al. (2010) melaporkan bahwa 6 species Chryseobacterium yang sebelumnya masuk dalam genus Flavobacterium merupakan bakteri yang nonmotile, positif katalase, positif oksidase, positif penghasil indol dan tidak mampu menggunakan glukosa dalam fermentasi. Chryseobacterium indologenes dapat ditemukan di alam secara mudah, tetapi bukan termasuk bakteri yang keberadaannya normal dan jarang yang bersifat patogen pada manusia, tetapi bersifat patogen di ikan. Karena itu, keberadaan bakteri ini di limbah pengolahan agar bukan indikasi limbah tersebut sudah tercemar oleh kotoran ataupun penanganan manusia, tetapi lebih pada keberadaan bakteri ini yang mudah ditemukan di alam dan kebetulan sesuai dengan kondisi limbah tersebut. Sampai dengan saat ini belum diperoleh informasi tentang selulase dari bakteri tersebut, Chryseobacterium sp telah dilaporkan Riffel \& Brandelli, 2002 dalam El-Ayouty et al. (2012) menghasilkan keratinase. Akan tetapi, selulase dari Flavobacterium sp. F 52 telah dilaporkan (Tsuji et al., 2013).

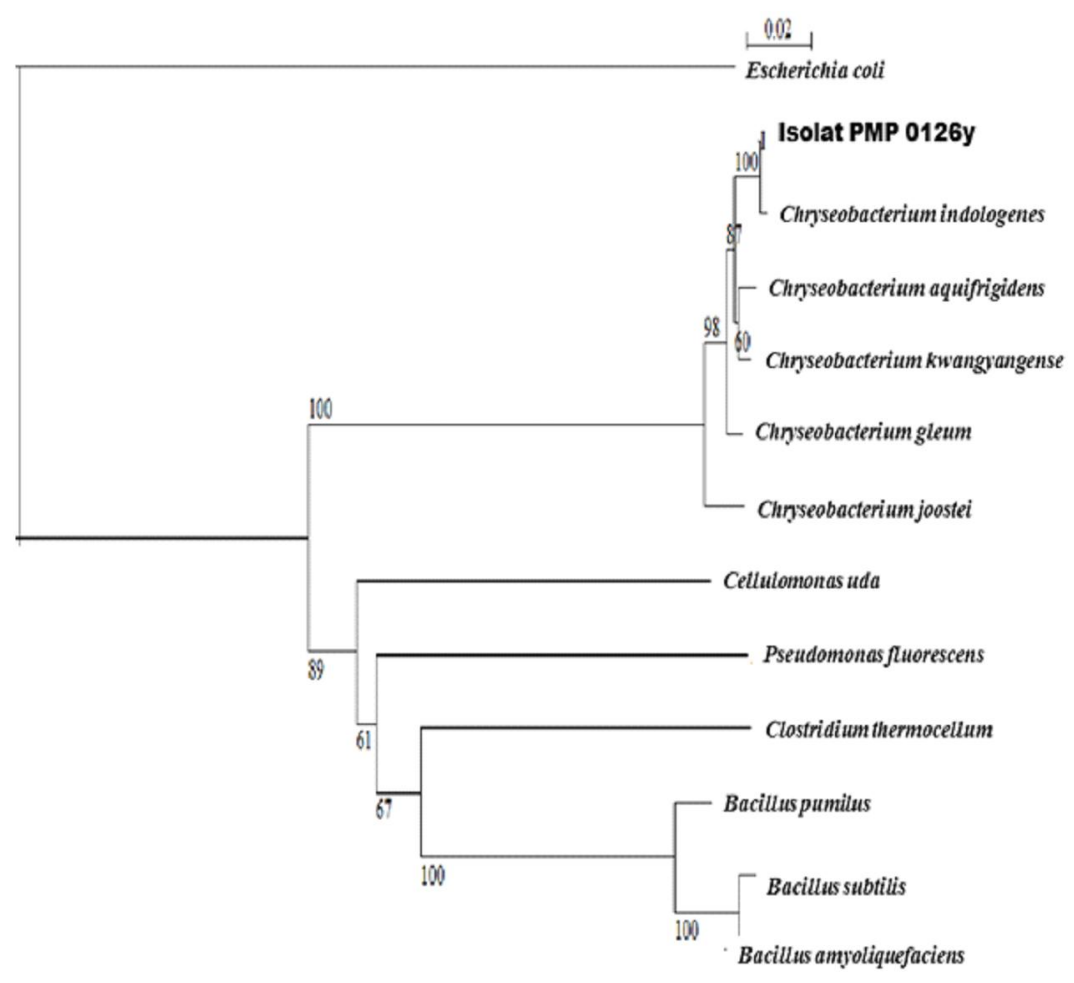

Gambar 1. Pohon filogenetik isolat PMP 0126Y.

Figure 1. Phylogenetic tree of isolat PMP 0126Y. 
Hasil isolasi selulase dari tanah peat menghasilkan bakteri selulolitik Bacillus pumilus, Bacillus cereus, Paenibacillus elgii, dan Bacillus sp. lainnya, di mana selulase yang dihasilkan dilaporkan bersifat thermozyme (Lisdiyanti et al., 2012). Dokumen FAO Corporate Document Repository tentang Renewable biological systems for alternative sustainable energy production menyebutkan bahwa fungi, Actinomycetes dan bakteri merupakan mikroorganisme penghasil selulase yang representatif, dan untuk bakteri penghasil selulase maka jenis yang sudah tercatat adalah Clostridium thermocellum, Ruminococcus albus, Streptomyces sp. (Anon., 2013). Trivedi et al. (2011) melaporkan bakteri selulolitik dari rumput laut Ulva lactuca yang memiliki kemiripan dengan Bacillus lectus strain SV6. Shanmunghapriya et al. (2010) telah mengisolasi bakteri selulolitik Marinobacter sp. (MSI032) dari spons laut Dendrilla nigra, sedangkan Gao et al. (2010) melaporkan Vibrio penghasil selulase dari tanah sekitar mangrove di perairan Cina.

Ketika ditumbuhkan pada media cair yang mengandung CMC $1 \%$, isolat PMP $0126 \mathrm{Y}$ segera masuk pada fase logaritmik sampai dengan jam ke 21 (hari 1), yang dilanjutkan dengan fase stasioner dan fase declining (Gambar 2). Dari Gambar 2 terlihat bahwa enzim selulase diproduksi mulai dari fase logaritmik dan maksimum pada fase stationer. Ini mengindikasikan bahwa isolat PMP 0126Y yang diperoleh dari limbah pengolahan agar memproduksi selulase sebagai alat untuk memecah selulosa yang ada di limbah tempat hidupnya untuk mendapatkan sumber $\mathrm{C}$ dan $\mathrm{N}$ sederhana yang bisa digunakan isolat tersebut untuk tumbuh. Produksi maksimal yang terdeteksi pada fase stationer diduga merupakan kumulatif dari produksi sebelumnya yang selanjutnya pada fase stationer enzim tersebut akan dirombak oleh isolat PMP 0126Y untuk mempertahankan hidupnya diantaranya sebagai sumber energi. Pada waktu puncak tersebut, aktivitas enzim yang didapatkan adalah $0,120 \mathrm{U} / \mathrm{ml}$. Penelitian yang dilakukan oleh Lisdiyanti et al. (2012) yang mengisolasi selulase dari bakteri selulolitik dari tanah peat (gambut) menghasilkan selulase dengan aktivitas $0,021-3,082 \mathrm{U} / \mathrm{ml}$. Jika dibandingkan dengan selulase dari tanah peat, selulase dari limbah pengolahan rumput laut untuk produksi agar masih dalam kisaran rendah, meskipun masih dalam kisaran aktivitas selulase yang didapat dari tanah gambut (peat). Produksi enzim ini selain ditentukan oleh jenis sumber enzim juga sangat ditentukan oleh komposisi medium (Deswal et al. 2011) dan konsentrasi substrat (Reczey et al. 1996).

Selanjutnya enzim diproduksi dengan menggunakan waktu produksi 3 hari (Gambar 2), suhu kultivasi $30^{\circ} \mathrm{C}$ di dalam penangas goyang (Shel Lab) dengan kecepatan agitasi $150 \mathrm{rpm}$. Enzim ekstraseluler kasar yang diperoleh kemudian dimurnikan. Pemurnian dilakukan dengan penukar ion, dengan menggunakan matriks DEAE Sepharose Fast Flow sebagai fase diam, dan gradien $\mathrm{NaCl}$ sebagai fase geraknya. Gambar 3 memperlihatkan profil pemurnian enzim selulase PMP 0126Y, yang memperlihatkan 1 puncak protein pada fraksi 49-51 elusi $\mathrm{NaCl} 0,406 \mathrm{M}$. Pengecekan dengan SDS-PAGE dan zimogram memperlihatkan bahwa hasil pemurnian fraksi 49-51, 52, dan 55 masih memiliki banyak pita protein, yang menandakan bahwa pemurnian dengan sistem tersebut masih belum mampu memurnikan secara maksimal. Secara umum, strategi pemurnian enzim melibatkan lebih dari 1 tahap pemurnian. Pada

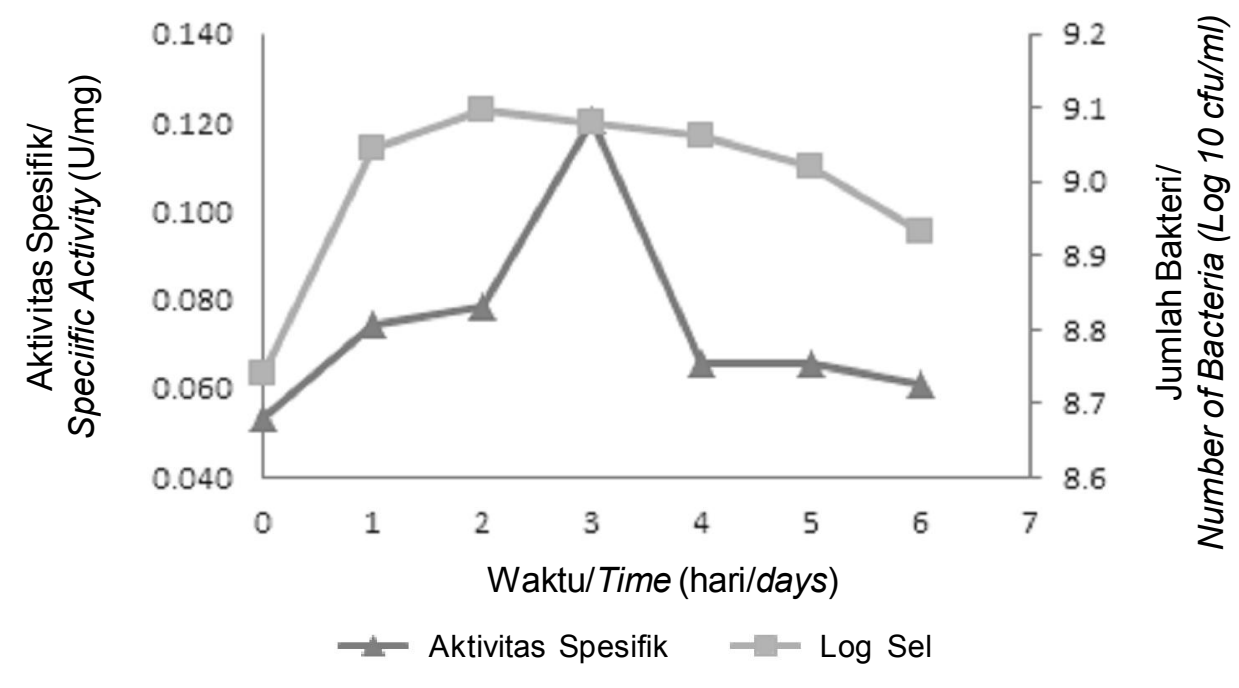

Gambar 2. Kurva produksi selulase dan jumlah sel bakteri PMP 0126Y selama pertumbuhan.

Figure 2. Production curve and cell number of PMP 0126Y isolate during cultivation. 
sistem pemurnian yang dilakukan oleh Li-Jung et al. (2010), enzim selulase murni terlihat sebagai pita tunggal ketika digunakan 2 sistem pemurnian yaitu sistem penukar ion yang dilanjutkan dengan sistem gel filtrasi. Hasil pemurnian selulase dari isolat PMP 0126Y telah diringkas pada Tabel 1, yang menunjukkan bahwa pemurnian dengan tahap pemurnian tunggal DEAE Sepharose ${ }^{T M}$ Fast Flow tersebut mampu meningkatkan aktivitas enzim sebesar $16 x$ dengan perolehan $5 \%$.

Hasil SDS-PAGE telah dikonfirmasi dengan analisis zimogram. Hasil zimogram ditandai dengan terbentuknya zona bening pada gel yang menunjukkan adanya aktivitas selulase yang dihasilkan pada gel akrilamida yang mengandung 0,1\% CMC. Hasil optimasi untuk mendapatkan visualisasi yang baik menunjukkan bahwa waktu inkubasi gel terbaik adalah 60 menit dengan menggunakan bufer sitrat fosfat $\mathrm{pH}$ 5 , setelah tahapan renaturasi dengan larutan 2,5\% Triton X-100 selama 1 jam. Hasil zimogram menunjukkan adanya tiga molekul protein yang memiliki aktivitas selulolitik dengan perkiraan berat molekul 39, 30, $14 \mathrm{kDa}$ yang dihitung berdasarkan mobilitas relatif terhadap standar protein (Gambar 5). Hasil penelitian tentang selulase dari Bacillus subtilis YJ1 melaporkan berat molekul selulase 32,5 kDa. Selulase dari Bacillus subtilis YJ1 dilaporkan telah dimurnikan dengan sistem yang sama yaitu penukar ion, dengan Macro-Prep yang dilanjutkan dengan sistem pemurnian dengan gel filtrasi Bio-Gel P-100 kromatografi dan berhasil mendapatkan satu pita protein murni. Perolehan yang didapat dengan sistem tersebut adalah 9,7\% (Li-Jung et al., 2010).

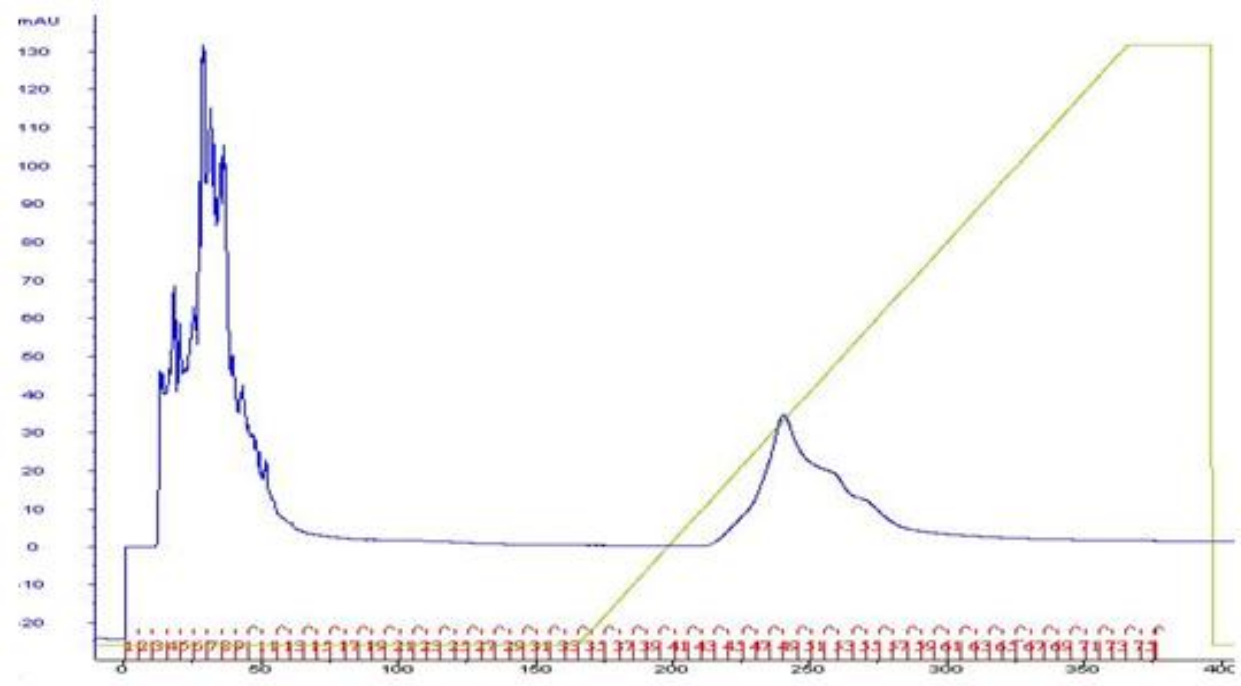

Gambar 3. Profil elusi selulase menggunakan penukar ion dengan matriks DEAE Sepharose.

Figure 3. Elution profile of cellulase using ion exchange of DEAE Sepharose matrix.

Tabel 1. Pemurnian partial selulase PMP 0126Y

Table 1. Partial purification of PMP 0126Y Celulase

\begin{tabular}{|c|c|c|c|c|c|c|c|}
\hline Tahap/Steps & $\begin{array}{l}\text { Volume } \\
\text { (ml) }\end{array}$ & $\begin{array}{c}\text { Aktivitas/ } \\
\text { Activity } \\
(\mathrm{U} / \mathrm{mI})\end{array}$ & $\begin{array}{l}\text { Aktivitas } \\
\text { Total/ } \\
\text { Total } \\
\text { Activity } \\
\text { (U) }\end{array}$ & $\begin{array}{c}\text { Konse ntrasi } \\
\text { Protein/ } \\
\text { Protein } \\
\text { Concentration } \\
(\mathrm{mg} / \mathrm{ml})\end{array}$ & $\begin{array}{c}\text { Aktivitas } \\
\text { spesifik/ } \\
\text { Specific } \\
\text { Activity } \\
\text { (U/mg) }\end{array}$ & $\begin{array}{c}\text { Kemurnian/ } \\
\text { Purity }\end{array}$ & $\begin{array}{c}\text { Hasil/ } \\
\text { Yield } \\
(\%)\end{array}$ \\
\hline $\begin{array}{l}\text { Ekstrak kasar/ } \\
\text { Crude Extract }\end{array}$ & 500 & 0.064 & 32.00 & 0.750 & 0.086 & 1.000 & 100 \\
\hline $\begin{array}{l}\text { Ultrafiltrasi/ } \\
\text { Ultrafiltration } \\
\text { Penukar ion/Ion }\end{array}$ & 50 & 0.112 & 5.60 & 0.822 & 0.136 & 1.581 & 17.5 \\
\hline $\begin{array}{l}\text { exchanger (fraksi/ } \\
\text { fraction } 49,50,51 \text { ) }\end{array}$ & 12 & 0.143 & 1.72 & 0.105 & 1.362 & 15.84 & 5.4 \\
\hline
\end{tabular}



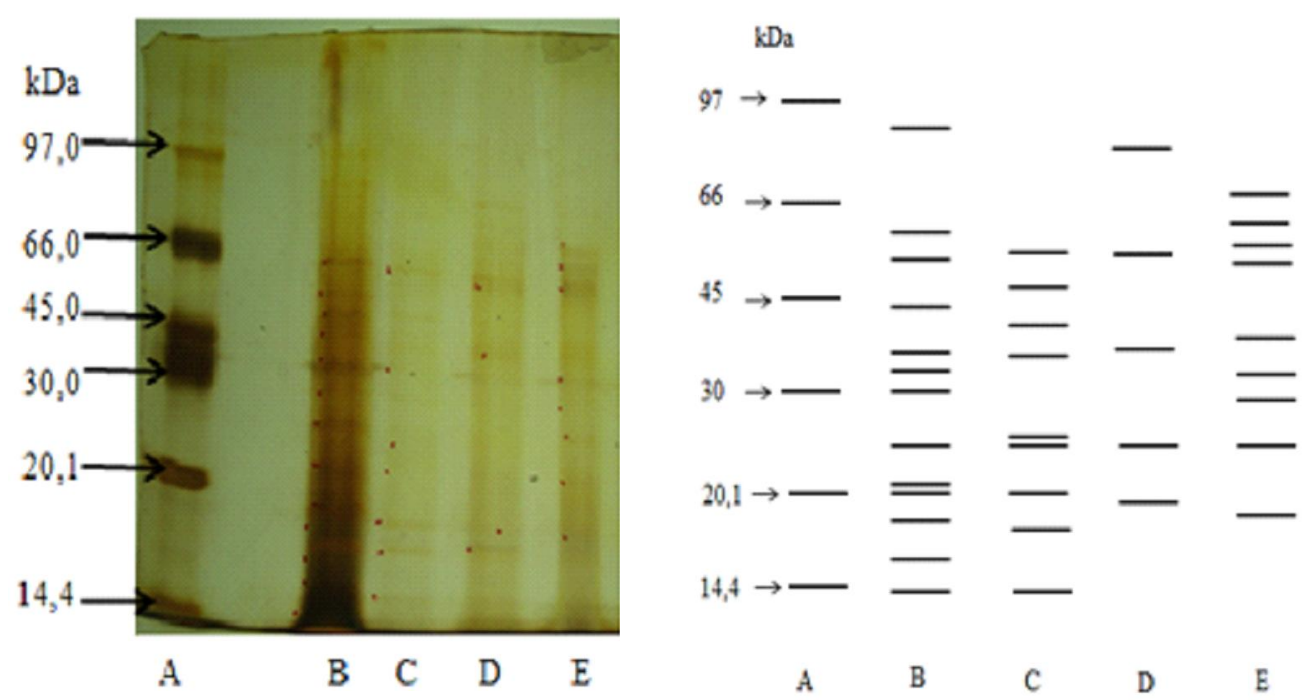

Gambar 4. Hasil elekroforesis SDS PAGE enzim dari PMP 0126Y. (A: Penanda berat protein rendah, B: Ultrafiltrasi, C: Fraksi 55, D: Fraksi 49-51, E: Fraksi 52).

Figure 4. Result of SDS-PAGE of PMP 0126Y cellulase crude enzyme. (A: Protein low molecular weight marker, B: Ultrafiltrasi, C: Fraksi 55, D: Fraksi 49-51, E: Fraksi 52).

Hasil karakterisasi enzim selulase menunjukkan bahwa enzim kasar dan enzim murni dari isolat PMP 0126Y menunjukkan $\mathrm{pH}$ optimum yang sama yaitu $\mathrm{pH} 5$ dengan bufer yang sesuai untuk selulase ini adalah bufer fosfat (Gambar 6). Namun demikian, terdapat pergeseran suhu optimal; enzim kasar memiliki suhu optimal untuk aktif pada $30^{\circ} \mathrm{C}$, sedangkan enzim yang telah dimurnikan secara parsial dengan kromatografi penukar anion memiliki suhu optimum $40^{\circ} \mathrm{C}$ (Gambar 7). Perbedaan ini disebabkan oleh masih terdapatnya materi-materi lain seperti garam, protein non enzim dan lain-lain, yang dapat berfungsi sebagai pelindung enzim.
Hasil uji stabilitas pada variasi suhu 30,40 , dan $50^{\circ} \mathrm{C}$ yang diperlakukan pada enzim selulase PMP 0126Y memperlihatkan bahwa sampai dengan 4 jam pengamatan enzim selulase relatif stabil pada ketiga suhu tersebut yang diperlihatkan dengan hasil bahwa ketiga perlakuan panas tidak menyebabkan penurunan aktivitas dibawah $50 \%$ aktivitas awal (Gambar 8 ).

Dibandingkan dengan selulase dari Bacillus flexus NT yang diisolasi dari rumput laut Ulva flexus yang dibusukkan, terdapat perbedaan karakter seperti berat molekul, pH dan suhu optimal enzim. Selulase dari limbah pengolahan agar yang diproduksi dari isolat PMP 012Y memiliki pH optimal 5 dan bekerja optimal

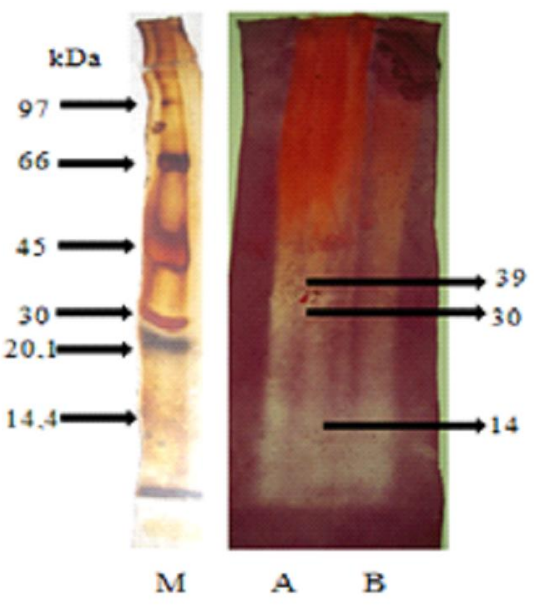

Gambar 5. Hasil zimogram PMP 0126Y (M: Marker protein rendah A : Enzim hasil ultrafiltrasi, B : Fraksi KPA.

Figure 5. Zymogram analysis of PMP 0126Y cellulase (Note : $M=$ marker; $A=$ crude enzyme; $B=$ enzyme from partial purification). 


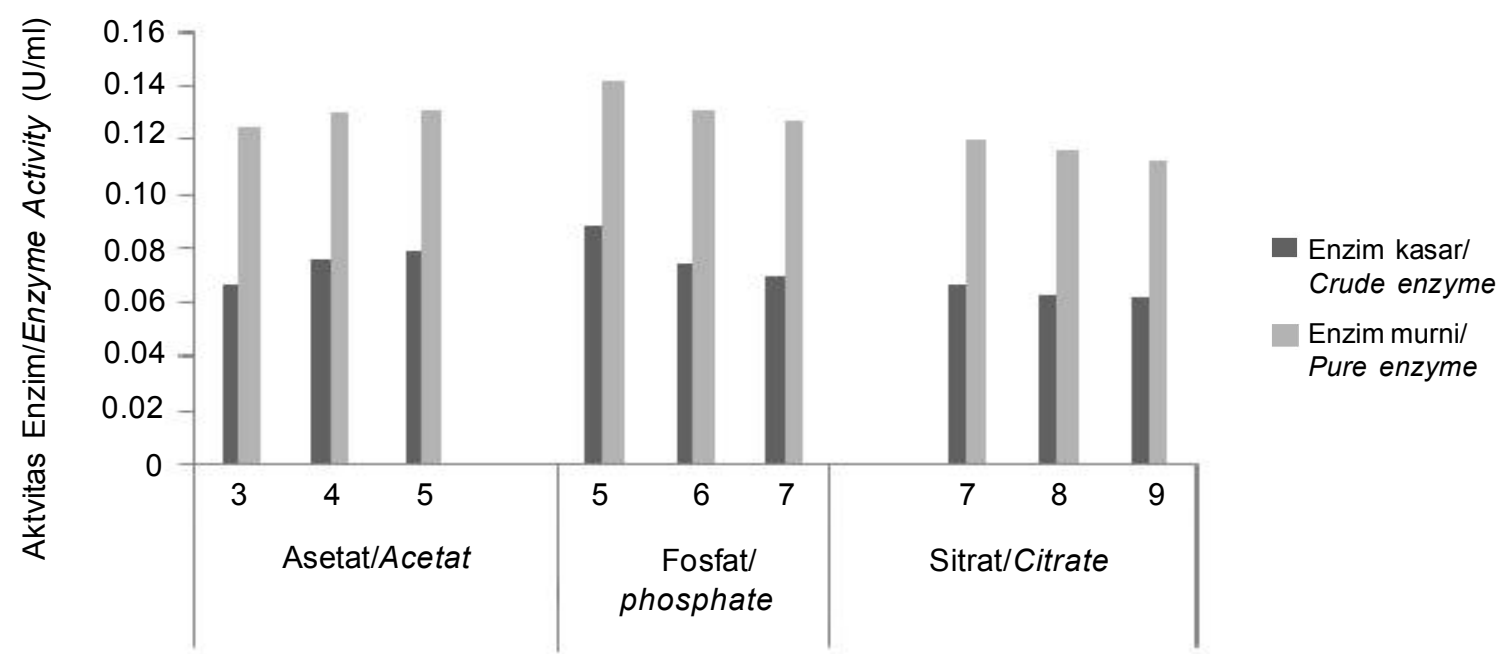

$\mathrm{pH}$ dan Bufer yang Digunakan/pH and Buffer Used

Gambar 6. Pengaruh $\mathrm{pH}$ terhadap aktivitas selulase PMP 0126Y. Figure 6. Effect of $\mathrm{pH}$ to PMP $0126 \mathrm{Y}$ cellulase.

pada suhu $30^{\circ} \mathrm{C}$, mampu ditingkatkan aktivitasnya oleh $\mathrm{Ca}^{2+}$ dan $\mathrm{Mg}^{2+}$ pada konsentrasi $5 \mathrm{mM}$ dan sedikit ditingkatkan oleh adanya $\mathrm{Fe}^{2+}$ dalam bentuk garam klorida. Selulase dari rumput laut Ulva flexus memiliki ketahanan terhadap alkali dan garam, $\mathrm{pH}$ dan suhu optimal 10 dan $45^{\circ} \mathrm{C}$, serta dapat ditingkatkan aktivitasnya oleh ion logam $\mathrm{Cd}^{2+}$ dan $\mathrm{Li}^{2+}$ dan dihambat oleh adanya $\mathrm{Cr}^{2+}, \mathrm{Co}^{2+}, \mathrm{Zn}^{2}$ (Trivedi et al. 2010). Perbedaan karakter tersebut disebabkan oleh banyak hal, diantaranya oleh sumber mikrobanya, serta lingkungan tempat mikroba tersebut diisolasi. Pada selulase yang diperoleh dari limbah pengolahan agar, tampaknya proses pengolahan mempengaruhi karakter dari selulasenya. Peningkatan aktivitas oleh ion Ca diduga karena dalam proses pengolahan agar, terdapat tahapan penambahan $\mathrm{CaO}(5 \%)$ yang ditujukan sebagai agen pemucat rumput laut, yang dilakukan pada tahap awal pengolahan. Selanjutnya dalam proses ekstraksi agar, $\mathrm{pH}$ yang digunakan adalah $\mathrm{pH}$ 5-6 yang ditujukan untuk mempermudah proses tersebut dengan penambahan asam asetat atau fosfat. Karena itu dapat dimengerti bahwa bakteri yang tumbuh di limbah pengolahan agar akan beradaptasi dengan kondisi ini dan mengeluarkan enzim yang bekerja yang sesuai dengan kondisi yang ada, diantaranya bekerja dengan baik pada $\mathrm{pH} 5$ dan adanya ion kalsium. Selain $\mathrm{Ca}$, ion $\mathrm{Mg}$ juga mampu meningkatkan aktivitas selulase yang diisolasi dari limbah pengolahan agar ini.

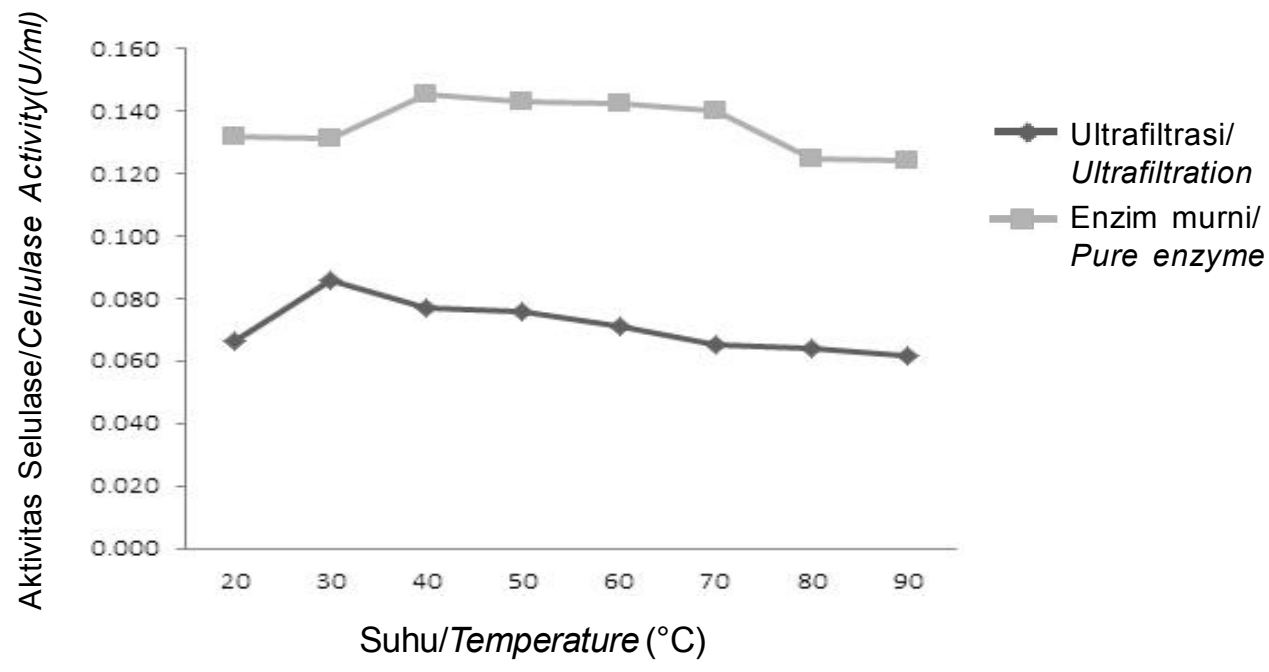

Gambar 7. Pengaruh suhu terhadap aktivitas selulase kasar dan murni dari PMP 0126Y.

Figure 7. Effect of temperature on crude and relatively pure PMP 0126Y cellulase. 


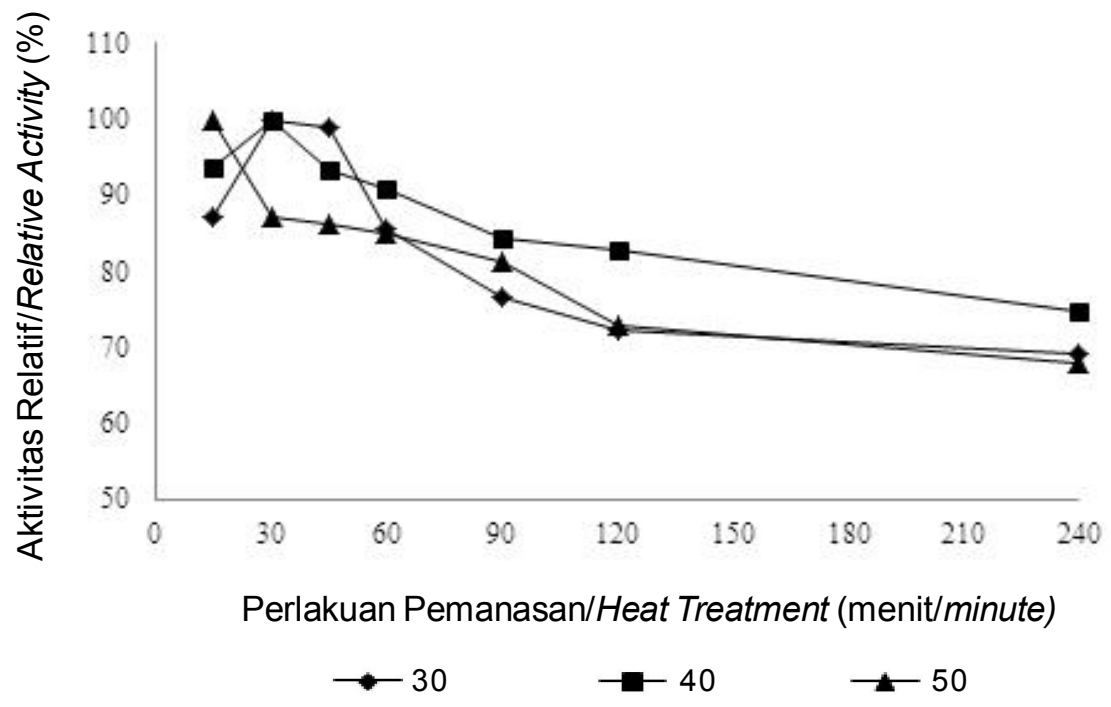

Gambar 8. Stabilitas panas selulase PMP $0126 \mathrm{Y}$ pada suhu $30^{\circ} \mathrm{C}, 40^{\circ} \mathrm{C}, 50^{\circ} \mathrm{C}$.

Figure 8. Heat stability of PMP $0126 \mathrm{Y}$ cellulase on $30^{\circ} \mathrm{C}, 40^{\circ} \mathrm{C}, 50^{\circ} \mathrm{C}$.

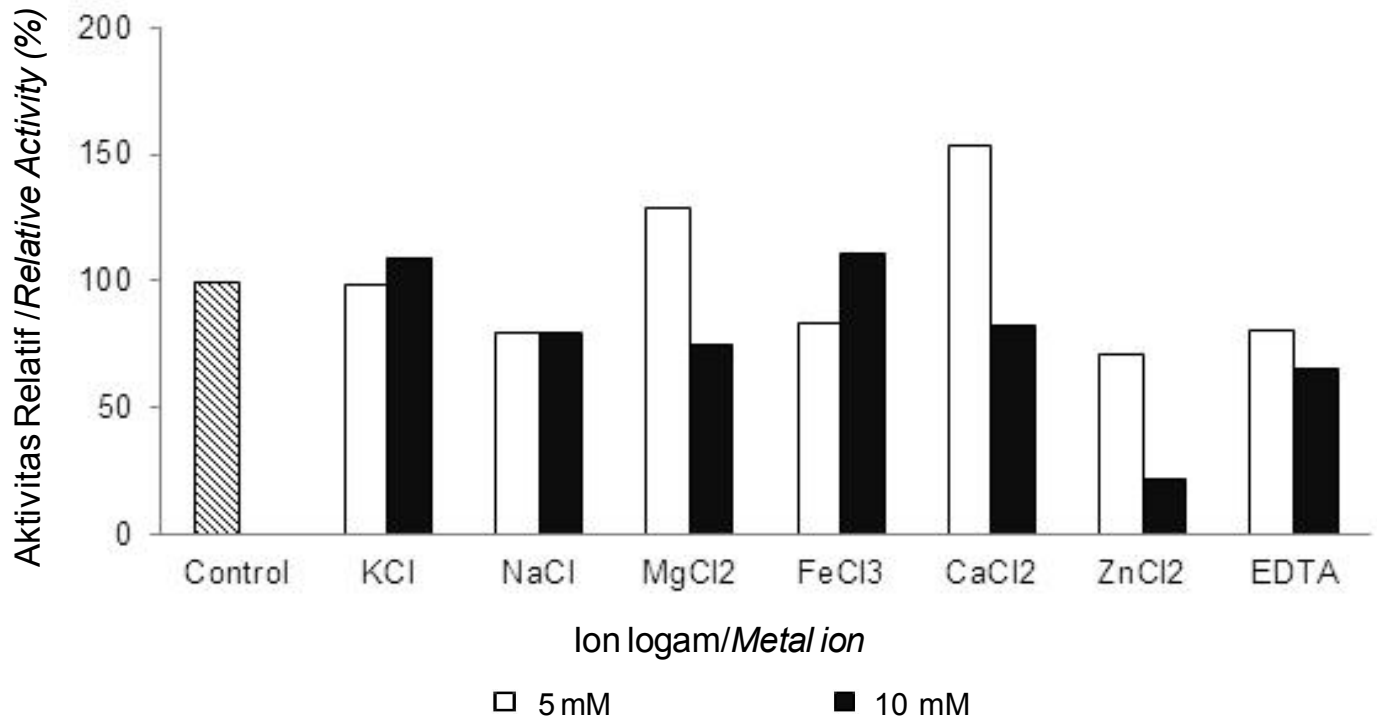

Gambar 9. Penambahan ion logam ( $5 \mathrm{mM}$ dan $10 \mathrm{mM})$ dan pengaruhnya terhadap aktivitas relatif selulase kasar dari isolat PMP 0126Y.

Figure 9. Addition of ion metal (5 mM dan $10 \mathrm{mM}$ ) and its effect to relative activity crude PMP 0126Y cellulase.

Pengujian aktivitas selulase PMP 012Y pada berbagai substrat menunjukkan bahwa aktivitas tertinggi dihasilkan ketika substrat yang digunakan adalah limbah rumput laut dari pengolahan agar yang diikuti dengan limbah rumput laut dari pengolahan agaragar PT. Agarindo, keduanya telah di pretreatment dengan $\mathrm{NaOH} 6 \%$ (Gambar 10). Pre treatment ditujukan untuk menyiapkan substrat agar lebih mudah diakses oleh enzim selulase. Dibanding dengan biomassa lignoselulosa dari limbah pertanian, biomasa dari makroalga atau rumput laut memiliki keuntungan dengan rendahnya lignin dan hemiselulosa. Dalam penelitian ini terlihat bahwa selulase PMP 0126Y mampu menggunakan limbah rumput laut yang telah diperlakukan dengan $\mathrm{NaOH}$ $6 \%$ sebagai substrat sebaik CMC murni dan teknis (Gambar 10).

Hasil penelitian ini menunjukkan bahwa selulase PMP 0126Y ini memiliki potensi untuk menjadi agen pendegradasi substrat limbah pengolahan rumput laut, 


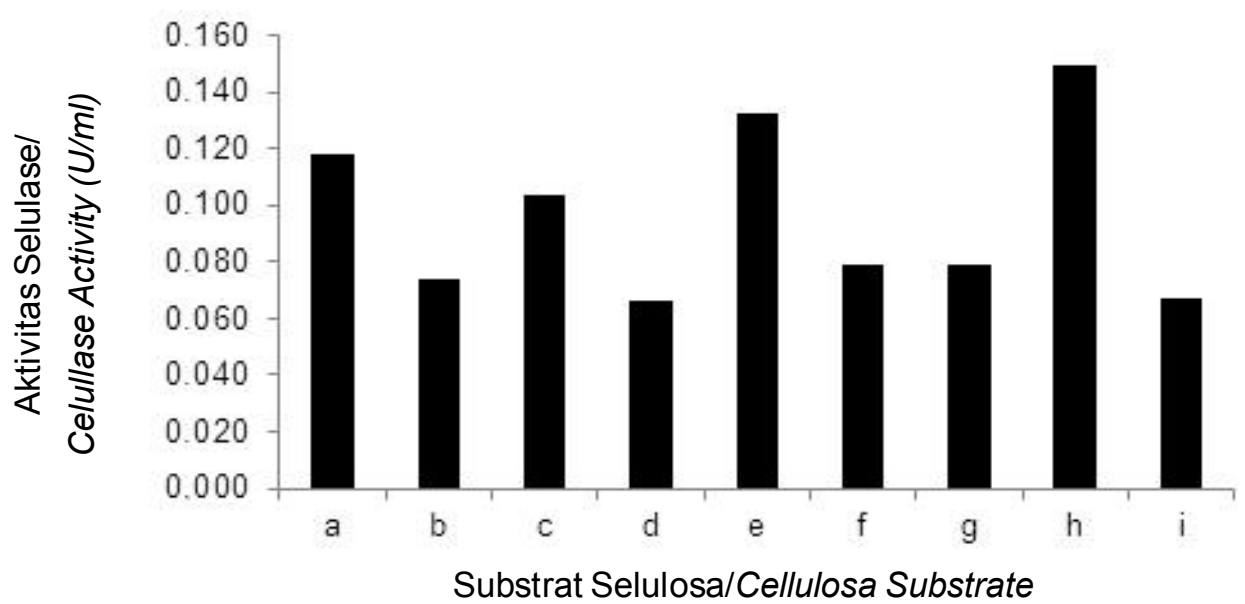

Gambar 10. Aktivitas selulase PMP 0126Y pada berbagai substrat (a. CMC murni, b. CMC teknis, c. Avisel, d. kertas Whatman No.1, e. limbah agar-agar PT Agarindo $\mathrm{NaOH} 6 \%$, f. limbah alginat, g. limbah agar-agar Pameungpeuk $\mathrm{NaOH} 4 \%$, h. limbah agar-agar Pameungpeuk $\mathrm{NaOH} 6 \%$, dan i. limbah agar-agar Pameungpeuk $\mathrm{H}_{2} \mathrm{SO}_{4} 1 \%$ ).

Figure 10. PMP 0126Y cellulase activity toward various substrate (a. pure CMC, b. technical CMC, c. Avisel, d. Whatman No.1, e. PT Agarindo waste treated with $\mathrm{NaOH} 6 \%$, f. Alginat processing waste, $g$. Waste from Pameungpeuk agar processing treated with $\mathrm{NaOH} 4 \%$, h. Waste from Pameungpeuk agar processing treated with $\mathrm{NaOH} 6 \%$, dan $i$. Waste from Pameungpeuk agar processing treated with $\mathrm{H}_{2} \mathrm{SO}_{4}$ 1\%).

yang terlebih dulu di perlakukan dengan $\mathrm{NaOH} 6 \%$. Aplikasi enzim ini dalam skala lebih besar diperlukan untuk pengecekan efisiensi enzim tersebut sebagai agen biologi dalam proses sakarifikasi limbah rumput laut pengolahan agar.

\section{KESIMPULAN}

Dari isolat PMP 0126Y yang memiliki kemiripan 96\% dengan Chryseobacterium indologenes galur McR-1 telah didapatkan enzim selulase yang dapat bekerja optimal pada $\mathrm{pH} 5$ dan suhu $30^{\circ} \mathrm{C}$. Enzim selulase tersebut mampu ditingkatkan aktivitasnya oleh $\mathrm{Ca}^{2+}$ dan $\mathrm{Mg}^{2+}$ pada konsentrasi $5 \mathrm{mM}$ dalam bentuk garam klorida. Keberadaan $\mathrm{ZnCl}_{2}$ baik pada konsentrasi 5 maupun $10 \mathrm{mM}$ dapat menghambat aktivitas enzim. Isolat PMP 0126Y memproduksi paling sedikit 3 selulase dengan perkiraan berat molekul 39, 30, dan $14 \mathrm{kDa}$ yang dapat dideteksi dari analisis zimogram. Selulase PMP 0126Y ini memiliki potensi sebagai agen sakarifikasi selulosa yang ada pada limbah pengolahan rumput laut karena mampu menghidrolisis limbah rumput laut sebaik substrat CMC.

\section{DAFTAR PUSTAKA}

Anonim. 2012. Roadmap Rumput Laut. Dirjen P2HP, KKP.

Anonymous. 2013. FAO Corporate document Repository onRenewable biological systems for alternative sustainable energy production.http : www. Publikasir/ 2013/bioethanol/3.2\%20Cellulase\%20production. $\mathrm{htm}$. Diakses pada tanggal 26 Juli 2013.

Arifin, H. 2006. Bacterial Cellulase from A Local Isolate Bacillus pumilus EB3. Tesis. Universitas Putra Malaysia, Kuala Lumpur.

Bollag, M.D. and Edelstein, S.J. 1991. Protein Method. New York: Wiley-Liss.

Bradford, M.M. 1976. A Rapid and sensitive methode for the quantitation of micogram quantitaties of protein in utilizing the principle of protein-dye Binding. J. Anal Biochem. 72: 248-254.

Choi, Chung, N.S.D.M., Ryu, C.H., Yoon, K.S., Maeng, P.J., and Kim, S.H. 2006. Identification of Three Extracellular Proteases from Bacillus subtilis KCTC 3014. J. Microbiol. Biotechnol. 16(3): 457-464.

Coral, G., Arikan, B., Nisa, U.M., and Guvenmez, H. 2002. Some properties of crude carboxylmethyl cellulase of Aspergillus niger Z10 wild-type strain. Turk. J. Biol. 26: 209-213.

Crueger, W. and Crueger, A. 1984. Biotechnology. In Brock T.D. (ed.). Textbook of Industrial Microbiology. Sunderland: Minuaer Associates. 267-276 pp.

Deswal, D., Khasa, Y.P., and Kuhad, R.C. 2011. Optimization of cellulase production by a brown rot fungus Fomitopsis sp. RCK2010 under solid state fermentation. Bioresour. Technol. 102: 6065-6072.

Gao, Z., Ruan, L., Chen, X., Zhang, Y., and Xu, X. 2010. A novel salt-tolerant endo-beta-1,4-glucanase Cel5A in Vibrio sp. G21 isolated from mangrove soil. Appl. Microbiol. Biotechnol. 87(4): 1373-1382.

Irawan, B., Sutihat, dan Sumardi. 2008. Uji aktivitas selulase dan lipase pada mikrofungi selama proses 
dekomposisi limbah cair kelapa sawit dengan pengujian kultur murni. Prosiding Seminar Hasil Penelitian dan Pengabdian kepada Masyarakat. Lampung: Universitas Lampung. 284-291 pp.

Kim, G.S., Myung, K.S., Kim, Y.J., Oh, K.K., Kim, J.S., Ryu, H.J., and Kim, K.H. 2008. Methode of Producing Biofuel Using Sea Algae. World Intelectual Property Organization, Seoul.

Lee, Y.K. 2006. Bioprocess technology In Microbial Biotechnology: Principles and Application, Edited by Yun Kun Lee. World Scientific Publishing, sec.ed. 23-72 pp.

Li-Jung Yin, Lin, H.H., and Xiao, Z.R. 2010. Purification and Characterization of A Cellulase from Bacillus Subtilis Yj1. Journal of Marine Science and Technology. 18(3): 466-471.

Lisdiyanti, P., Suyanto, E., Gusmawati, N.F., and Rahayu, W. 2012. Isolation and characterization of cellulase produced by cellulolytic bacteria from peat soil of Ogan Komering Ilir, South Sumatera. International Journal of Environment and Bioenergy. 3(3): 145153.

Mangunwardoyo, W., Aprilismulan, Oetari, A., and Sjamsuridzal W. 2011. Screening Cellulose Activity of Yeast Isolated from Soil, Sediment and Water Riverfrom Taman Nasional Gunung Halimun, West Java, Indonesia. Malaysian Journal of Microbiology. 7(4): 210-216.

Meryandini, A., Widosari, W., Maranatha, B., Sunarti, T.C., Rachmania N., dan Satria, H. 2009. Isolasi bakteri selulolitik dan karakterisasi enzimnya. Makara Sains. 13(1): 33-38.

Munifah, I., Chasanah, E. and Fawzya, Y.N. 2011. Screening of cellulolytic bacteria from Indonesia's marine environment. Di dalam: Prosiding Seminar ISISM (International Seminar of Indonesian Society for Microbiology); Bogor, 26 Juni 2011. Perhimpunan Mikrobiologi Cabang Bogor, Bogor.

Choi, N.S., Chung, D.M., Ryu, C.H., Yoon, K.S., Maeng, P.J., and Kim, S.H. 2006. Identification of three extracellular proteases from Bacillus subtilis KCTC 3014. J. Microbiol. Biotechnol. 16(3): 457-464
Reczey, K., Szengyel, Z., Eklund, R., and Zacchi, G. 1996. Cellulase production by Trichodermareesei. Bioresour. Technol. 57: 25-30.

Riyanti, E.I. 2008. Biomassa sebagai bahan baku Bioetanol. Balai Besar Penelitian dan Pengembangan Bioteknologi dan Sumberdaya Genetika Pertanian, Institut Pertanian Bogor, Bogor.

Shanmunghapriya, S., Kira, G.S., Selvin, J., Thomas, T.A., and Rani C. 2010. Optimization, Purification, and Characterization of Extracellular Mesophilic Alkaline Cellulase from Sponge-Associated Marinobacter sp. MSI032. Applied Biochemistry \& Biotechnology. 162(3): 625-640.

Suwanto, Yogiana, Suryanto, D., Tan, I., and Puspitasari, E. 2000. Selectes Protocols Training Course on Advances in Molecular Biology Techniques to Asses Microbial Diversity. Bogor: SEAMEO-BIOTROP. p. 2231.

Trivedi, N., Gupta, V., Kumar, M., Kumari, P., Reddy, CRK., and Jha, B. 2011. An alkali-halotolerant cellulase from Bacillus flexus isolated from green seaweed Ulva lactuca. Carbohyd Polym. 83: 891-897.

Tsuji, A., Tominaga, K., Nishiyama, N., and Yuasa, K. 2013. Comprehensive enzymatic analysis of the cellulolytic system in digestive fluid of the sea hare Aplysia kurodai. Efficient Glucose Release from Sea Lettuce by Synergistic Action of $45 \mathrm{kDa}$

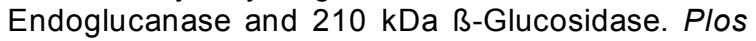
One Journal. 8(6): e65418.

Van de Peer Y. and De Watcher. 1993. TREECON: a software package for the construction and drawing of evolutionary trees. Comput. Applic Biosci. 9: 177182.

Yassin, M., El-Ayouty, Amira EL-said, and SaLama, A.M. 2012. Purification and characterization of a keratinase from the feather-degrading cultures of Aspergillus flavipes. African Journal of Biotechnology. 11(9): 2313-2319.

Lina, Yi-Tsung., Jeng, Yuan-Yu., Lin, M.L., Yua, K.W., Wang, F.D., and Liu, C.Y. 2010. Clinical and microbiological characteristics of Chryseobacterium indologenes bacteremia. J. Microbiol Immunol Infect 43(6): 498-505. 